\title{
CP Gene
}

National Cancer Institute

\section{Source}

National Cancer Institute. CP Gene. NCI Thesaurus. Code C104137.

This gene is a metalloprotein involved in copper binding in plasma. 